\title{
ARTICLES
}

\section{Ventilatory Responses to Hypercapnia and Hypoxia in Conscious Cystic Fibrosis Knockout Mice Cftr ${ }^{-/-}$}

\author{
MONIQUE BONORA, JEAN-FRANCOIS BERNAUDIN, CLAUDE GUERNIER, AND \\ MARIE CHRISTIANE BRAHIMI-HORN \\ Laboratoire de Physiologie Respiratoire [M.B.], Faculté de Médecine St-Antoine, 75012 Paris, France; \\ Laboratoire d'Histologie [J.-F.B, C.G.], Faculté de Médecine St-Antoine, 75012 Paris, France; and \\ INSERM U402 [C.B.-H], Faculté de Médecine St-Antoine, 75012 Paris, France.
}

\begin{abstract}
This study was designed to examine the ventilatory performance and the lung histopathology of cystic fibrosis knockout mice $\left(\mathrm{Cftr}^{-/-}\right)$compared with heterozygous $\left(\mathrm{Cftr}^{+/-}\right)$or wildtype $\left(\mathrm{Cftr}^{+/+}\right)$littermates. Ventilation was recorded in conscious animals using whole-body plethysmography. Tidal volume $\left(\mathrm{V}_{\mathrm{T}}\right)$, respiratory frequency $(f)$, and minute ventilation $\left(V_{E}\right)$ were measured during air breathing and in response to various levels of hypercapnia $\left(2,4,6\right.$, or $\left.8 \% \mathrm{CO}_{2}\right)$ or hypoxia $(14,12,10$, or $8 \%$ $\mathrm{O}_{2}$ ). The results for $\mathrm{Cftr}^{+/-}$and $\mathrm{Cftr}^{+/+}$were pooled into one control group because they did not differ. In air and in response to hypercapnia, $\mathrm{V}_{\mathrm{E}}, \mathrm{V}_{\mathrm{T}}$, and $\mathrm{f}$ were similar in $\mathrm{Cftr}^{-/-}$mice and in controls. During graded hypoxia, $\mathrm{V}_{\mathrm{E}}$ was decreased in $\mathrm{Cftr}^{-/-}$ mice at 10 and $8 \% \mathrm{O}_{2}$ because of a lower f. Histology showed neither inflammation nor obstruction of airways in $\mathrm{Cftr}^{-1-}$ mice. Morphometric analysis showed alveolar dilation as a result of
\end{abstract}

Lung disease is the leading cause of mortality in patients with cystic fibrosis (CF). The major alterations in lung function result from increased airway resistance as a result of the obstruction of small airways. This is mainly characterized by diminished flow rates, ventilation-perfusion inequalities, and abnormal blood gas values (1). In addition, children with CF show impaired ventilatory control with a decrease in the ventilatory response to hypercapnia (2-4) and hypoxia (2). These blunted ventilatory responses were attributed to decreased performance of the respiratory apparatus under the abnormal respiratory load caused by chronic airway disease $(2,3)$.

Received April 7, 2003; accepted November 18, 2003.

Correspondence: Monique Bonora, M.D., Inserm E213, Croissance et Réparation du Poumon, Hôpital Saint-Antoine, Bât, Raoul Kourilsky 184, rue du Fg Saint-Antoine, 75571 Paris Cedex 12; e-mail: bonora@st-antoine.inserm.fr

This work was supported by grants from the Association "Vaincre la Mucoviscidose" (Grant SI A 98001) and UPRES (EA 2397 and EA 34997).

DOI: 10.1203/01.PDR.0000117841.81730.2B either distension or impaired development. In conclusion, cystic fibrosis knockout mice have normal baseline breathing and ventilatory response to hypercapnia but a decreased ventilatory response to severe hypoxia. This latter result associated with the morphometric analysis suggests that $\mathrm{Cftr}^{-1-}$ mice may exhibit immaturity of the respiratory system. (Pediatr Res 55: 738-746, 2004)
Abbreviations
Cftr, cystic fibrosis transmembrane conductance regulator
CF, cystic fibrosis
$\mathbf{V}_{\mathbf{E}}$, minute ventilation
$\mathbf{V}_{\mathbf{T}}$, tidal volume
f, respiratory frequency
BW, body weight

$\mathrm{CF}$ is caused by mutations in the $\mathrm{CF}$ transmembrane conductance regulator gene (Cftr), which was cloned and characterized in 1989 (5). Several strains of mice defective in Cftr function have been developed in the past $10 \mathrm{y}$, and these animal models for $\mathrm{CF}$ are now widely used for research into gene therapy (6). In contrast to $\mathrm{CF}$ patients, $\mathrm{Cftr}^{-1-}$ mice do not develop life-threatening lung disease, but they often die from severe intestinal disease shortly after weaning (6). However, their respiratory tract exhibits some pathologic changes, such as dilation of the glandular ducts in the upper airways, a modest increase in the number of goblet cells in the distal airways (7), and reduced elastic recoil of the lungs (8). Despite this minor lung pathology, the incidence of this airway phenotype on respiratory function of $\mathrm{Cftr}^{-/-}$mice is still unknown. This study was designed to advance the evaluation of $\mathrm{Cftr}^{-1-}$ mice as a model for the human cystic fibrosis by exploring the ventilatory performances of $\mathrm{Cftr}^{-/-}$mice in response to hypercapnia or to hypoxia compared with wild-type mice. The 
ventilatory protocol was completed by histologic and morphometric analysis of the lungs.

\section{METHODS}

Animals. Female and male 129/BC mice heterozygous for the S489X mutation were crossed to obtain homozygous S489X mice (7). Three back-crosses into C57BI/6 (three generations) and then intercrosses between heterozygotes were performed. Only male mice were used in this study. Mice were housed and bred at the Center de Développement des Techniques avancées pour l'Expérimentation Animale (CDTEA of CNRS, Orléans, France) on wood shaving bedding and fed ad libitum on a standard diet. They had free access to drinking water and were maintained in a sterile environment with a 12-h light-dark cycle. All animal procedures were performed in accordance with institutional guidelines. Mice homozygous for the S489X mutation were classified as $\mathrm{Cftr}^{-/-}$, mice heterozygous for the S489X mutation as $\mathrm{Cftr}^{+/-}$, and wild-type mice as $\mathrm{Cftr}^{+/+}$. The study was carried out on 24 awake animals of 4 to 6 wk with a mean body weight (BW; \pm SEM) of $9.1 \pm 0.4 \mathrm{~g}$ $\left(\mathrm{Cftr}^{-/-}, n=12\right), 16.2 \pm 1.1 \mathrm{~g}\left(\mathrm{Cftr}^{+-}, n=6\right)$, and $15.2 \pm$ $1.1 \mathrm{~g}\left(\mathrm{Cftr}^{+/+}, n=6\right)$.

Measurements. Ventilatory parameters were recorded in a whole-body plethysmograph by the barometric method described by Bartlett and Tenney (9). The pressure signal as a result of breathing was detected by a differential pressure transducer (Validyne MP45, Northridge, CA, U.S.A.) connected to the animal chamber $(400 \mathrm{~mL})$ and to a reference chamber of the same volume. The spirogram was recorded on a strip-chart recorder (Graphtec, Japan) and also stored on a computer using respiratory acquisition software (CIO-DAS 1602/12 interface and ACQUIS1 software) for analysis offline. Calibration was performed at the beginning of experiments by several injections of $0.1 \mathrm{~mL}$ of air into the chamber.

Each animal was weighed and placed in the chamber preheated to $28-30^{\circ} \mathrm{C}$; a thermistal probe (BIO-BIT14) was gently inserted into the colon and secured in place at the base of the tail and on the wall chamber. A protecting muff opened to both ends was then placed around the mouse, allowing it to feel secure and to become rapidly calmed. During all studies, the ventilatory parameters and colonic and chamber temperature were determined at 5-min intervals.

Protocols. Recordings of ventilation were performed when the mice were quiet, although not in deep or rapid eye movement sleep, which could be roughly estimated from their behavior, the response to noise, and the pattern of breathing. Measurements were made during air breathing four times during a 20 -min period to obtain baseline values. Subsequently, the animal was exposed to four levels of hypercapnia in normoxia with the following sequence: $2,4,6$, and $8 \%$, each gas challenge being given for $10 \mathrm{~min}$. After a 20 -min interval in air, another baseline air value was obtained during a 20-min period, and then the animal was exposed to four levels of ambient hypoxia with the following sequence: 14, 12, 10, and $8 \%$, each gas challenge being given for $10 \mathrm{~min}$. Finally, the animal was allowed to recover in normoxia for $10 \mathrm{~min}$. The $\mathrm{CO}_{2}$ concentration in the chamber was always $<1 \%$ at the end of each session. This protocol was carried out three times on consecutive days for each mouse. However, three of 12 $\mathrm{Cftr}^{-1-}$ mice died before the end of the hypoxic protocol, and only one or two complete experiments were performed. Even though the protocol was similarly applied to the 12 control group mice without any problem, it is possible that $\mathrm{Cftr}^{-/}$ mice were more fragile.

Histology. Morphologic analysis of the lungs was performed in 18 mice (nine $\mathrm{Cftr}^{-/-}$, four $\mathrm{Cftr}^{+/-}$, and five $\mathrm{Cftr}^{+/+}$). At the end of the third ventilatory experiment, the mice were anesthetized with Urethan $(1.8 \mathrm{~g} / \mathrm{kg}$, i.p.). After exsanguination, the chest was opened, the trachea was exposed, and the lung was perfused in situ with $10 \%$ (vol/vol) neutral-buffered formalin under $5 \mathrm{~cm} \mathrm{H}_{2} 0$ pressure as recommended by Kent $e t$ al. (personal communication). Thereafter, the trachea was ligated and the lungs were excised and submerged in fixative for $5 \mathrm{~d}$ before embedding in paraffin.

Four-micrometer serial sections of the two lungs were cut and stained with hematoxylin and eosin or Masson's trichrome. Sections that yielded maximum visualization of the lung parenchyma were selected for morphometric studies using digitized image analysis (10). Digitized images from parenchymal fields were captured using a Laborlux D Leitz microscope (Leica SA, Rueil Malmaison, France) with a monocad Sony videocamera interfaced with a computer equipped with the histo software from Biocom (Biocom Imaging Division, Les Ulis, France). Sampled digital images were filtered, binarized, and segmented into two components, background and structures of interest, i.e. interalveolar septa.

For each animal, the total length of the tissue/air interface, i.e. corresponding to the alveolar boundary length, was measured in four different $5 \times 10^{5}-\mu \mathrm{m}^{2}$ parenchymal fields chosen devoid of large conductive airways, arteries, or veins. These measurements, therefore, evaluated the alveolar boundary length density expressed in $\mu \mathrm{m} / 10^{4} \mu \mathrm{m}$ (2) unit of parenchymal surface (11). Morphometric assessments were performed blind.

Analysis of results and statistics. The following variables were measured and calculated by a computer-assisted method: tidal volume $\left(\mathrm{V}_{\mathrm{T}}\right)$, respiratory frequency $(\mathrm{f})$, and minute ventilation $\left(\mathrm{V}_{\mathrm{E}}\right)$. For each 5-min recording, values were averaged on 50-100 contiguous breaths and then averaged for the three experiments performed on each mouse. No major difference was observed between the values of the three measurements for each experimental condition. Because of a large difference in the $\mathrm{BW}$ between $\mathrm{Cftr}^{-/-}$and $\mathrm{Cftr}^{+/+}$or $\mathrm{Cftr}^{+/-}$mice, $\mathrm{V}_{\mathrm{T}}$ and $\mathrm{V}_{\mathrm{E}}$ were normalized to $\mathrm{BW}$ by using allometric equations determined from mean values of the three groups using leastsquare linear regression after log transformation of the data. Ventilatory values are presented as mean \pm SEM of all animals for each genotypic group.

Statistical comparison of the results was performed first between wild-type $\left(\mathrm{Cftr}^{+/+}\right)$and heterozygous $\left(\mathrm{Cftr}^{+/-}\right)$mice, and if there was no statistical difference between these two groups, then their values were averaged and compared with the values of $\mathrm{Cftr}^{-/-}$mice. The $t$ test and multiple comparison test (Bonferroni) were used to compare the data (12). Differences were considered significant at $p<0.05$. 
Table 1. Characteristics of wild-type $\left(\mathrm{Cftr}^{+/+}\right)$, heterozygous $\left(\mathrm{Cftr}^{+/-}\right)$, and homozygous $\left(\mathrm{Cftr}^{-/-}\right)$mice breathing room air

\begin{tabular}{lccrr}
\hline & $\mathrm{Cftr}^{+/+}$ & $\mathrm{Cftr}^{+/-}$ & $\mathrm{Cftr}^{-/-}$ & $\mathrm{Cftr}^{+/+}+\mathrm{Cftr}^{+/-}$ \\
\hline$n$ & 6 & 6 & 12 & 12 \\
Age $(\mathrm{d})$ & $32.6 \pm 2.7$ & $30.8 \pm 2.2$ & $30.1 \pm 1.1$ & $31.7 \pm 1.8$ \\
$\mathrm{BW}(\mathrm{g})$ & $15.2 \pm 1.1$ & $16.2 \pm 1.1$ & $9.1 \pm 0.4$ & $15.7 * \pm 2.8$ \\
$\mathrm{Tc}\left({ }^{\circ} \mathrm{C}\right)$ & $37.9 \pm 0.1$ & $37.8 \pm 0.2$ & $37.4 \pm 0.2$ & $37.9^{*} \pm 0.1$ \\
$\mathrm{~V}_{\mathrm{E}}(\mathrm{mL} / \mathrm{min})$ & $28.1 \pm 1.2$ & $30.0 \pm 2.1$ & $19.7 \pm 1.3$ & $29.0^{*} \pm 1.2$ \\
$\mathrm{~V}_{\mathrm{E}}\left(\mathrm{mL} \cdot \mathrm{min}^{-1} \cdot \mathrm{g}\right)$ & $1.89 \pm 0.13$ & $1.88 \pm 0.16$ & $2.16 \pm 0.08$ & $1.89 * \pm 0.10$ \\
$\mathrm{~V}_{\mathrm{E}}\left(\mathrm{mL} \cdot \mathrm{min}^{-1} \cdot \mathrm{g}^{-0.73}\right)$ & $3.91 \pm 0.20$ & $3.95 \pm 0.28$ & $3.91 \pm 0.17$ & $3.93 \pm 0.17$ \\
$\mathrm{~V}_{\mathrm{T}}(\mu \mathrm{L})$ & $146.1 \pm 8.8$ & $171.2 \S \pm 9.6$ & $122.5 \pm 8.8$ & $158.6^{*} \pm 7.5$ \\
$\mathrm{~V}_{\mathrm{T}}(\mu \mathrm{L} / \mathrm{g})$ & $9.74 \pm 0.50$ & $10.66 \S \pm 0.47$ & $13.39 \pm 0.53$ & $10.20^{*} \pm 0.37$ \\
$\mathrm{~V}_{\mathrm{T}}\left(\mu \mathrm{L} / \mathrm{g}^{0.62}\right)$ & $27.13 \pm 1.02$ & $30.51 \S \pm 1.06$ & $30.91 \pm 1.47$ & $28.82 \pm 0.88$ \\
$\mathrm{f}(\mathrm{b} / \mathrm{min})$ & $195.9 \pm 10.9$ & $179.1 \pm 15.8$ & $167.7 \pm 11.3$ & $187.5 \pm 9.9$ \\
\hline
\end{tabular}

Mean values ( \pm SEM) of age, BW, colonic temperature $(\mathrm{Tc}), \mathrm{V}_{\mathrm{E}}, \mathrm{V}_{\mathrm{T}}$, and $\mathrm{f}$ in $\mathrm{Cftr}^{+/+}, \mathrm{Cftr}^{+/-}$, and $\mathrm{Cftr}^{-/-}$mice.

* Significantly different from $\mathrm{Cftr}^{-/-}$mice $(p<0.05)$.

$\S$ Significantly different from $\mathrm{Cftr}^{+/+}$mice $(p<0.05)$.

\section{RESULTS}

Weight development. The mean age $( \pm \mathrm{SEM})$ of the homozygous mice knockout for the gene $\mathrm{Cftr}\left(\mathrm{Cftr}^{-/}\right)$, wildtype $\left(\mathrm{Cftr}^{+/+}\right)$, and heterozygous $\left(\mathrm{Cftr}^{+/-}\right)$mice was $30.1 \pm$ $1.1,30.8 \pm 2.2$, and $32.6 \pm 2.7 \mathrm{~d}$, respectively. We selected this age because homozygous $\mathrm{Cftr}^{-1-}$ mice exhibit a high rate of mortality after weaning $(6,13)$. However, although the three groups of mice were matched for age, their BW was significantly different. As shown in Table 1, homozygous mice $\left(\mathrm{Cftr}^{-/-}\right)$are markedly smaller than wild-type $\left(\mathrm{Cftr}^{+/+}\right)$and heterozygous $\left(\mathrm{Cftr}^{+/-}\right)$mice, whereas $\mathrm{Cftr}^{+/+}$and $\mathrm{Cftr}^{+/-}$ mice show a similar BW. The weight-age relationships for the three groups are given in Figure 1. They show that both groups of $\mathrm{Cftr}^{+/+}$and $\mathrm{Cftr}^{+/-}$mice gained weight with age, whereas no significant correlation exists between these two factors in $\mathrm{Cftr}^{-1-}$ mice.

Respiratory variables in normoxia. Table 1 shows that during room air breathing, $\mathrm{V}_{\mathrm{E}}(\mathrm{ml} / \mathrm{min})$ in heterozygous mice was not different from that of $\mathrm{Cftr}^{+/+}$mice, whereas $\mathrm{V}_{\mathrm{E}}$ in $\mathrm{Cftr}^{-/-}$mice was much smaller compared with either $\mathrm{Cftr}^{+/-}$ or $\mathrm{Cftr}^{+/+}$groups. Although these absolute $\mathrm{V}_{\mathrm{E}}$ values have an intrinsic physiologic meaning, they often need to be normalized when animals have different sizes. The normalizing factor that is more commonly used for respiratory variables is the BW; however, when the BWs are within a large range, as in the present work, the relationships are not linear. Thus, the relationships between ventilatory variables and $\mathrm{BW}$ of the three groups of mice can be satisfactorily expressed by allometric equations $\left(\mathrm{y}=\mathrm{a} \cdot \mathrm{BW}^{\mathrm{b}}\right)$, where $b$ represents the slope of the relationship (14). The allometric relationships of $V_{E}, V_{T}$, and $f$ represented in Figure 2 shows that $\mathrm{V}_{\mathrm{E}}$ and $\mathrm{V}_{\mathrm{T}}$ are $\mathrm{BW}$ dependent with slopes of 0.73 and 0.62 , respectively, whereas the slope of $\mathrm{f}$ is not significantly different from zero. It indicates, therefore, a relatively higher $\mathrm{V}_{\mathrm{E}}$ and $\mathrm{V}_{\mathrm{T}}$ in the smaller animals. In normoxia, $\mathrm{V}_{\mathrm{E}}$ related to $\mathrm{BW}^{0.73}, \mathrm{~V}_{\mathrm{T}}$ related to $\mathrm{BW}^{0.62}$, and $\mathrm{f}$ are similar in $\mathrm{Cftr}^{-/-}$mice and in the group including $\mathrm{Cftr}^{+/+}$ and $\mathrm{Cftr}^{+/-}$mice (Table 1).

Ventilatory responses to hypercapnia and hypoxia. An example of a typical pattern of ventilation during normoxia, $8 \% \mathrm{CO}_{2}$ and $8 \% \mathrm{O}_{2}$ in conscious wild-type $\left(\mathrm{Cftr}^{+/+}\right)$mice, is shown in Figure 3, and the average response in $\mathrm{V}_{\mathrm{E}}, \mathrm{V}_{\mathrm{T}}$, and $\mathrm{f}$ to graded levels of hypercapnia in the three groups of mice is

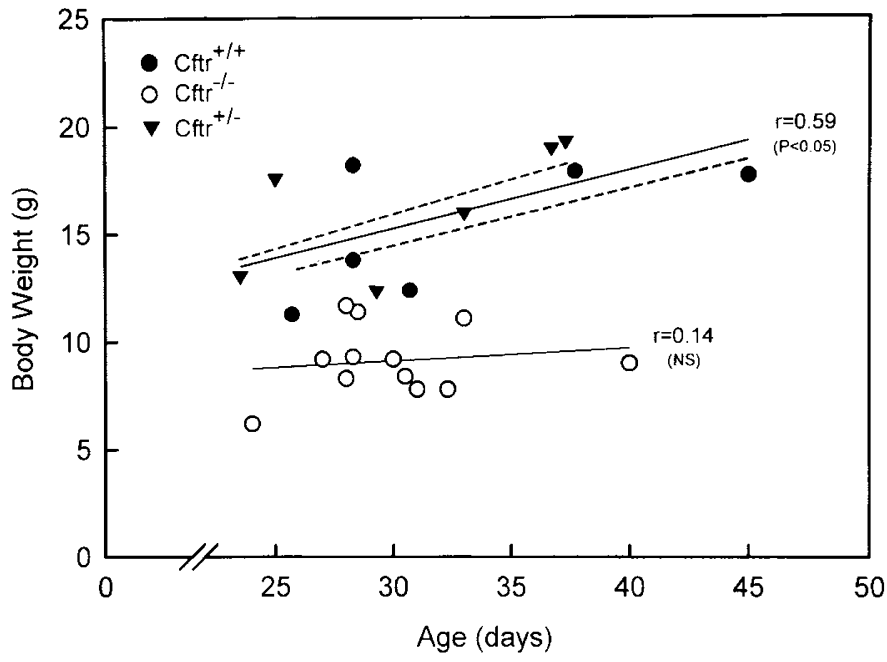

Figure 1. Relationships between $\mathrm{BW}$ and age for $\mathrm{Cftr}^{+/+}$mice $(\mathbf{0} ; n=6)$, $\mathrm{Cftr}^{+-}$mice $(\nabla ; n=6)$, and $\mathrm{Cftr}^{-/-}$mice $(\bigcirc ; n=12)$. The regression lines fitted for values of $\mathrm{Cftr}^{-/-}$mice and for $\mathrm{Cftr}^{+/+}$and $\mathrm{Cftr}^{+/-}$mice (solid lines) and for values of each group of $\mathrm{Cftr}^{+/+}$and $\mathrm{Cftr}^{+/-}$mice (dotted lines), with correlation coefficients $(\mathrm{r})$ and $p$ value $(p<0.05)$ are shown.

presented in Figure 4. Figure 4 shows that the response of $V_{E}$ to hypercapnia is similar in the three groups at all levels of inspired $\mathrm{CO}_{2}$, but slight differences are observed in the breathing pattern, i.e. $\mathrm{V}_{\mathrm{T}}$ is slightly higher in $\mathrm{Cftr}^{+/-}$than in $\mathrm{Cftr}^{+/+}$ at $2 \% \mathrm{CO}_{2}$, and $\mathrm{f}$ is slightly lower in $\mathrm{Cftr}^{-/-}$than in the whole group of $\mathrm{Cftr}^{+/+}$and $\mathrm{Cftr}^{+/-}$mice at 2 and $4 \% \mathrm{CO}_{2}$. During the hypercapnic session, the rectal temperature decreased similarly in control and $\mathrm{Cftr}^{-/}$mice (from $37.7 \pm 0.1^{\circ} \mathrm{C}$ to 37.3 $\pm 0.1^{\circ} \mathrm{C}$ and from $37.3 \pm 0.2^{\circ} \mathrm{C}$ to $36.9 \pm 0.1^{\circ} \mathrm{C}$, respectively).

Figure 5 shows that exposure to varying levels of hypoxia induced an augmentation in $\mathrm{V}_{\mathrm{E}}$ in the three groups mainly as a result of an increase in $\mathrm{f}$. Comparison of the values for $\mathrm{Cftr}^{+/+}$ and $\mathrm{Cftr}^{+/-}$mice for the three parameters shows that the response to hypoxia did not differ, but $\mathrm{Cftr}^{-/-}$mice values of $\mathrm{V}_{\mathrm{E}}$ at 10 and $8 \% \mathrm{O}_{2}$ are smaller than in the two other groups because of a lower $\mathrm{f}$. During the hypoxic session, the rectal temperature decreased slightly less in control than in $\mathrm{Cftr}^{-/}$ mice (from $37.4 \pm 0.1^{\circ} \mathrm{C}$ to $36.9 \pm 0.2^{\circ} \mathrm{C}$ and from $37.2 \pm$ $0.2^{\circ} \mathrm{C}$ to $36.4 \pm 0.1^{\circ} \mathrm{C}$, respectively), this difference being particularly marked when switching from 10 and $8 \% \mathrm{O}_{2}$. 

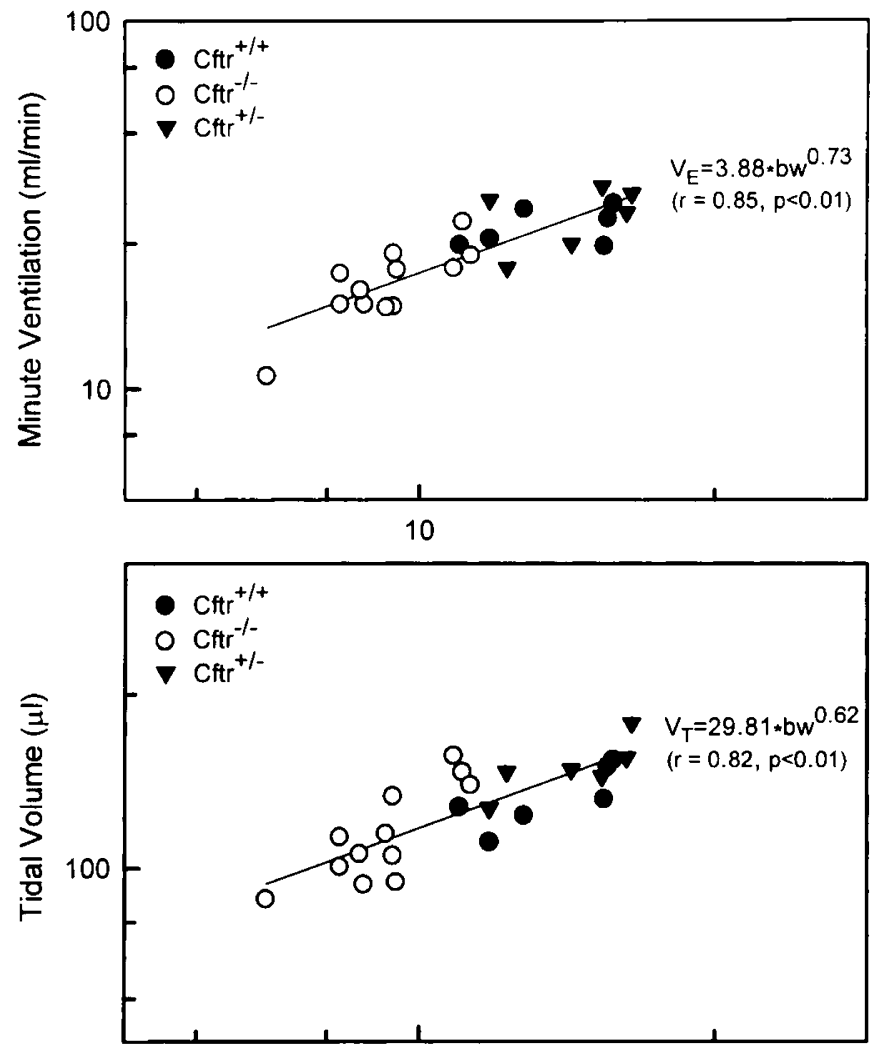

10

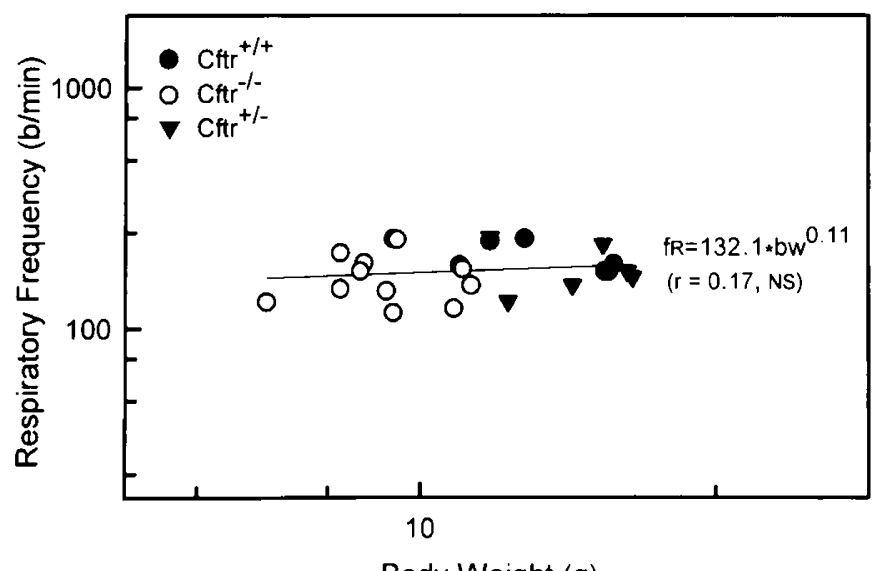

Body Weight $(\mathrm{g})$

Figure 2. Allometric relationships between $\mathrm{BW}$ and $\mathrm{V}_{\mathrm{E}}, \mathrm{V}_{\mathrm{T}}$, or $\mathrm{f}$ for $\mathrm{Cftr}^{+/+}$ and $\mathrm{Cftr}^{+/-}$mice $(\mathbf{O} ; n=12)$ and $\mathrm{Cftr}^{-/-}$mice $(\bigcirc ; n=12)$ in air. The log-log linear regressions through all of the data with correlation coefficient (r) and $p$ value $(p<0.05)$ and the allometric equations of the form $\mathrm{y}=\mathrm{a} . \mathrm{BW}^{\mathrm{b}}$ are indicated.

Measurement of ventilatory responsiveness to chemoreceptor inputs in the three groups was assessed by calculating the percentage changes in $\mathrm{V}_{\mathrm{E}}, \mathrm{V}_{\mathrm{T}}$, and $\mathrm{f}$ during the highest levels of hypoxia and hypercapnia relative to room air (Fig. 6). Figure 6 shows that the percentage change in $\mathrm{V}_{\mathrm{E}}$ in response to $8 \%$ $\mathrm{CO}_{2}$ is similar in the three groups of mice, whereas the percentage change in $\mathrm{V}_{\mathrm{E}}$ in response to $8 \% \mathrm{O}_{2}$ is significantly lower in $\mathrm{Cftr}^{-/-}$than in $\mathrm{Cftr}^{+/+}$and $\mathrm{Cftr}^{+/-}$mice, this effect being due to a lower increase in $\mathrm{f}$. Also, the responses of heterozygous $\mathrm{Cftr}^{+/-}$mice to $8 \% \mathrm{CO}_{2}$ or $8 \% \mathrm{O}_{2}$ in regard to $\mathrm{V}_{\mathrm{E}}, \mathrm{V}_{\mathrm{T}}$, and $\mathrm{f}$ are similar to that of wild-type mice. This figure
NORMOXIA

$250 \mu \mathrm{I}$

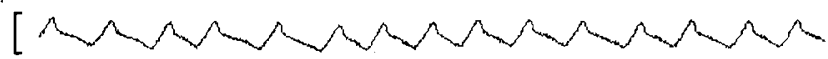

HYPERCAPNIA $\left(8 \% \mathrm{CO}_{2}\right)$

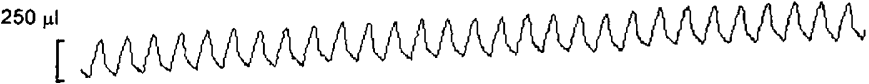

HYPOXIA $\left(8 \% \mathrm{O}_{2}\right)$

$250 \mu$

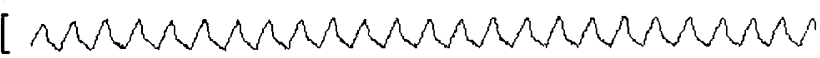

1s

Figure 3. Representative tracings of an experiment during normoxia, hypercapnia, or hypoxia in a wild-type conscious mouse.

also indicates that in all groups of mice, exposure to either hypercapnia or hypoxia induced a relatively larger increase in $\mathrm{f}$ than in $\mathrm{V}_{\mathrm{T}}$.

Lung histology and morphometric analysis. Histopathology examination of the lungs of the different groups of mice, whatever their Cftr status, did not show any fibrosis, inflammation, or remodeling of intrapulmonary airways, as well as lung parenchyma. No structural change, as the presence of goblet cells or luminal obstruction, was observed at the level of intrapulmonary airways, associated with the $\mathrm{Cftr}^{-/-}$genotype, except for a mild distension of the alveolar air spaces (Fig. 7).

Results of the morphometric analysis of the alveolar boundary length densities are shown in Figure 8. Comparison of the results (mean values $\pm \mathrm{SD}$ ) obtained for the nine mice of the $\mathrm{Cftr}^{-/-}$group (791 $\pm 60 \mu \mathrm{m} /$ field) with those from the group composed of the five $\mathrm{Cftr}^{+/+}$and the four $\mathrm{Cftr}^{+/-}$mice $(914 \pm$ $63 \mu \mathrm{m} /$ field $)$ showed a highly significant $(p=0.009)$ lower alveolar boundary length density in the $\mathrm{Cftr}^{-/-}$mice.

\section{DISCUSSION}

In the present study, we mainly examined resting breathing in air and the respiratory responses to hypoxia and hypercapnia in knockout mice for CFTR function compared with wild-type or heterozygous mice. The results provide evidence that $\mathrm{V}_{\mathrm{E}}$ of $\mathrm{Cftr}^{-1-}$ mice is not affected during normoxia and in response to various levels of hypercapnia, although the $\mathrm{f}$ is slightly lower than for controls at 2 and $4 \% \mathrm{CO}_{2}$. In contrast, $\mathrm{V}_{\mathrm{E}}$ is markedly diminished in response to severe hypoxia in $\mathrm{Cftr}^{-1-}$ mice because of a lower $\mathrm{f}$. In addition, the histologic analysis of the lung shows no major morphologic changes, except dilated alveolar morphology in $\mathrm{Cftr}^{-/-}$mice.

Considerations of methods. We measured the respiratory variables by body plethysmography that is a downsized modification of that used in awake rats (9). The reliability of this noninvasive method to measure ventilation in awake animals 

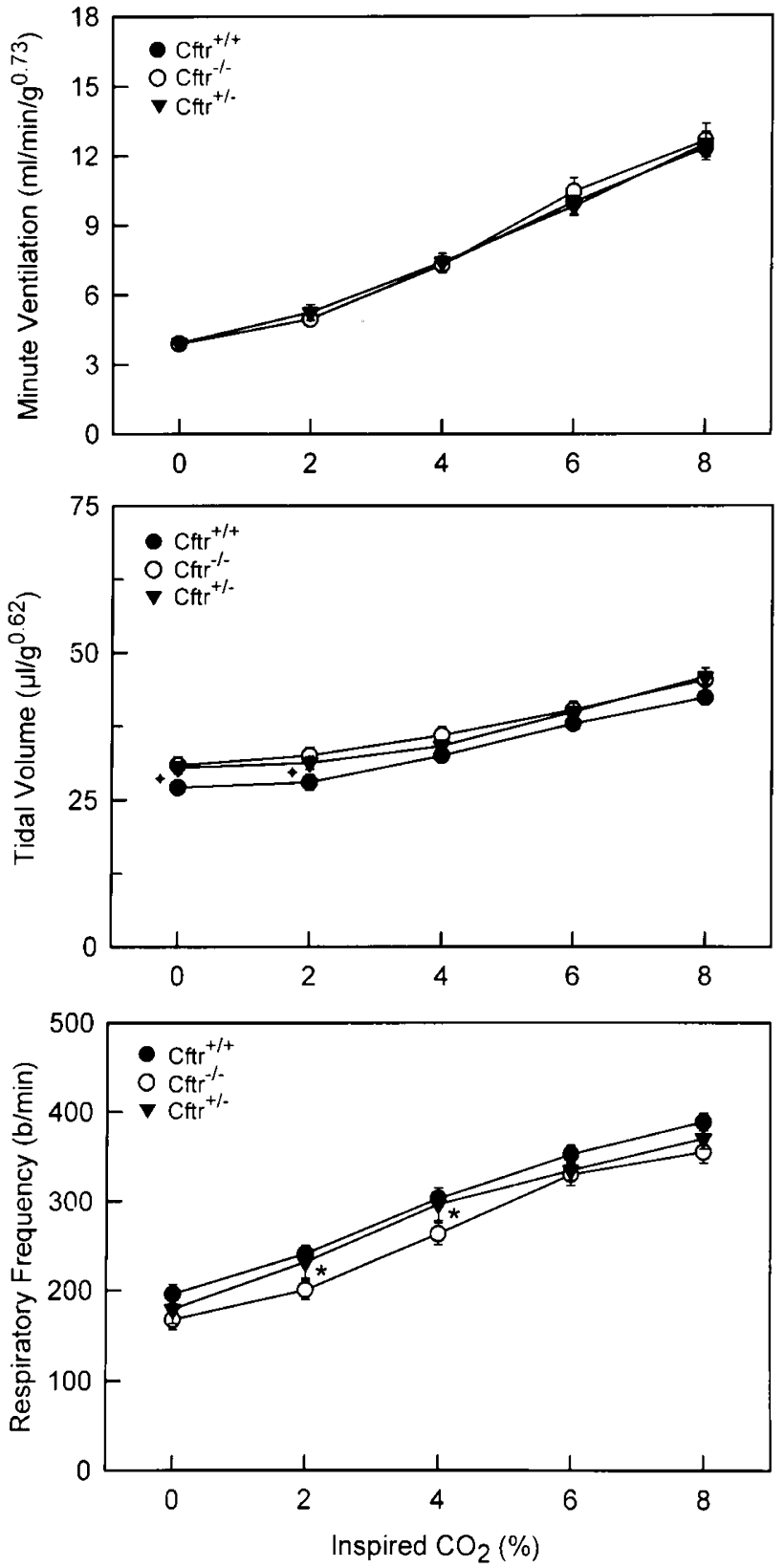

Figure 4. Mean values ( $\pm \mathrm{SE})$ of $\mathrm{V}_{\mathrm{E}}, \mathrm{V}_{\mathrm{T}}$, and $\mathrm{f}$ in $\mathrm{Cftr}^{+/+}(\boldsymbol{\bullet} ; n=6), \mathrm{Cftr}^{+/-}$ $(\mathbf{v} ; n=6)$, and $\mathrm{Cftr}^{-/-}(\bigcirc ; n=12)$ mice in air and in four levels of hypercapnia $\left(2,4,6\right.$, and $8 \%$ of inspired $\mathrm{CO}_{2}$ in air). Significant differences between $\mathrm{Cftr}^{+/+}$and $\mathrm{Cftr}^{+/-}$mice; * significant differences between the whole group of $\mathrm{Cftr}^{+/+}$and $\mathrm{Cftr}^{+/-}$mice and the group of $\mathrm{Cftr}^{-/-}$mice; $p<0.05$.

can be questioned for the measurement of $\mathrm{V}_{\mathrm{T}}$, which can be underestimated (15), but this technique, which is routinely applied to mice (16), has been validated against pneumotachography and direct plethysmography (17) with a systemic error on $\mathrm{V}_{\mathrm{T}}$ of $<7 \%$. In addition, the same equipment was used for the three genotypic groups; thus, the comparison between them cannot affect the interpretation of the results. Also, it was changes in respiratory timing, not $\mathrm{V}_{\mathrm{T}}$, that accounted for the reduced hypoxic response in the $\mathrm{Cftr}^{-/-}$mice.

Ventilation. In our wild-type mice, the $\mathrm{V}_{\mathrm{E}}$ normalized to $\mathrm{BW}$ values are similar to that reported for mice of the same age
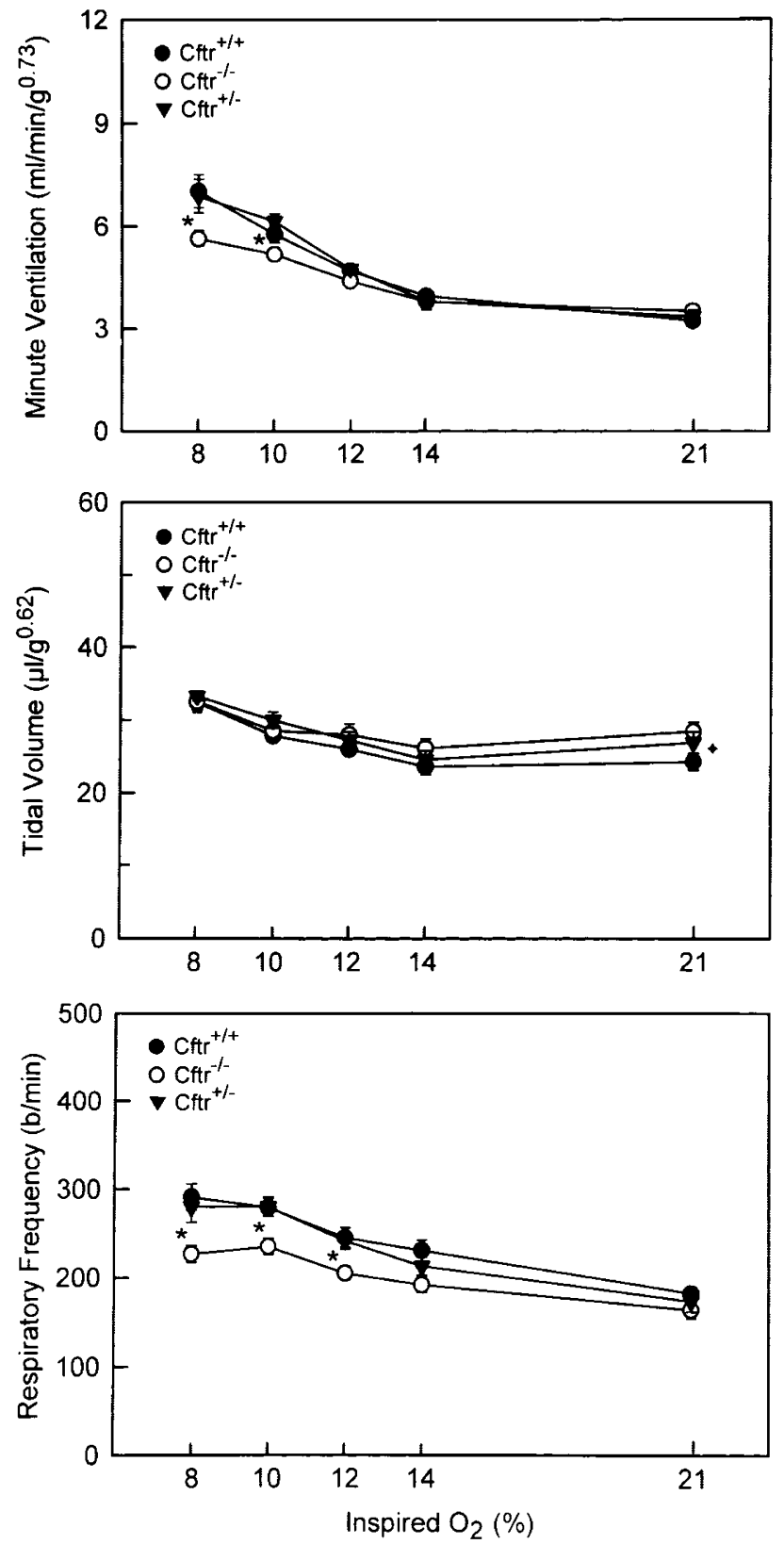

Figure 5. Mean values ( $\pm \mathrm{SE}$ ) of $\mathrm{V}_{\mathrm{E}}, \mathrm{V}_{\mathrm{T}}$, and $\mathrm{f}$ in $\mathrm{Cftr}^{+/+}(\mathbf{O} ; n=6), \mathrm{Cftr}^{+/-}$ $(\mathbf{\nabla} ; n=6)$, and $\mathrm{Cftr}^{--}(\bigcirc ; n=12)$ mice in air and in four levels of hypoxia $\left(14,12,10\right.$, and $8 \%$ of inspired $\left.\mathrm{O}_{2}\right)$. Significant differences between $\mathrm{Cftr}^{+/+}$ and $\mathrm{Cftr}^{+/-}$mice; *significant differences between the whole group of $\mathrm{Cftr}^{+/+}$ and $\mathrm{Cftr}^{+-}$mice and the group of $\mathrm{Cftr}^{-/-}$mice; $p<0.05$.

and BW (18), but they are slightly greater than those reported for larger mice $(16,17,19)$. This result can be partly explained by the nonlinearity of the relationships between the ventilatory parameters and $\mathrm{BW}$ when the $\mathrm{BW}$ range is large. However, the comparison of the ventilatory data of the $\mathrm{Cftr}^{-/-}$mice with those of wild-type mice of similar BW would have suggested the use of much younger wild-type mice, thus with an immature CNS. We therefore chose to compare the results between mice of the same age and overcome the problem of the large BW difference by normalizing the ventilatory data with allometric relationships that have been previously validated for intraspecies comparisons (20). 

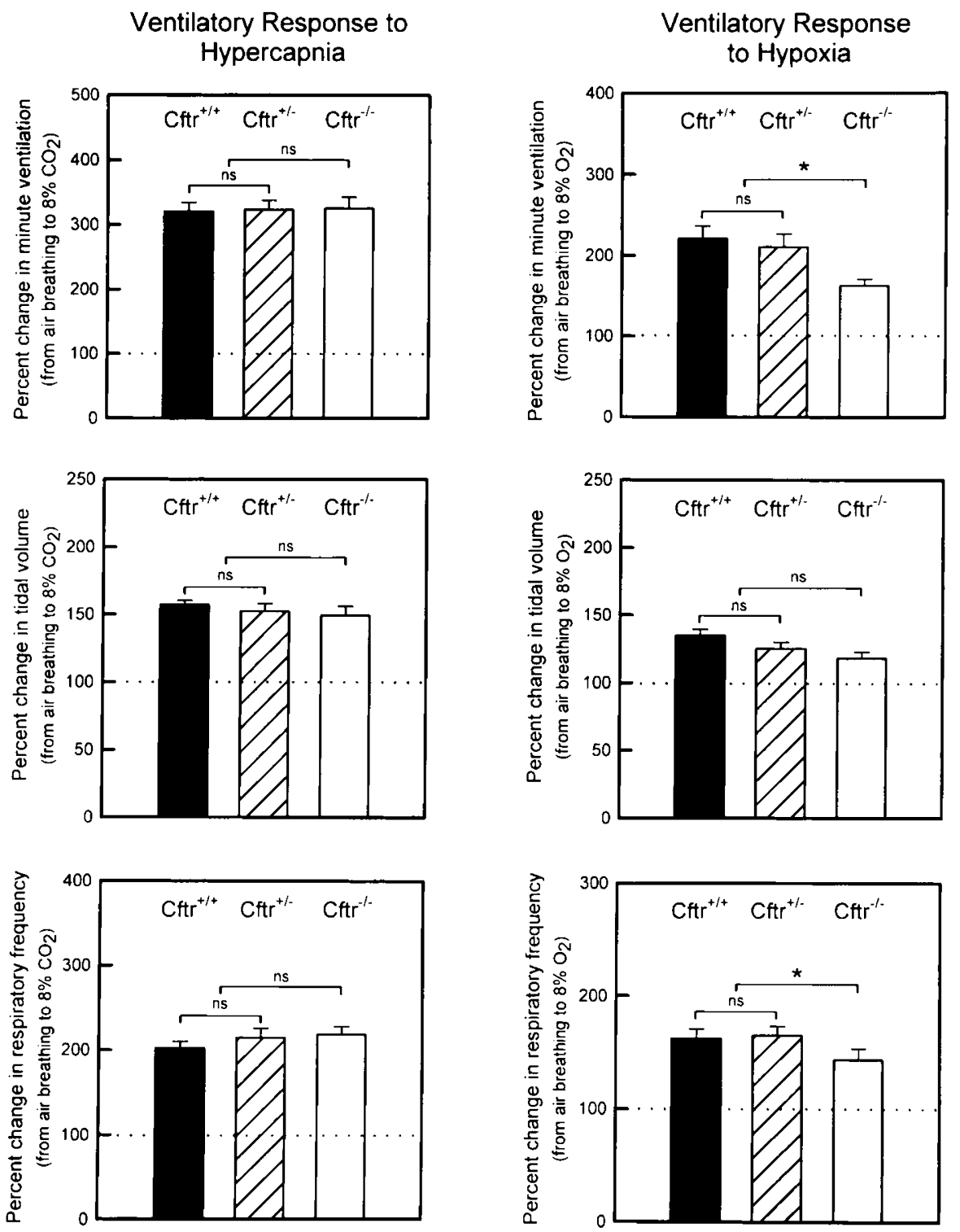

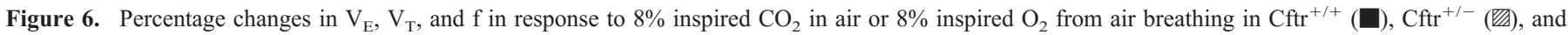
$\mathrm{Cftr}^{-1-}(\square)$ mice. *Significant differences between groups; $p<0.05$.

The present study showed that in $\mathrm{Cftr}^{-/-}$mice, normoxic $\mathrm{V}_{\mathrm{E}}$, allometrically normalized to $\mathrm{BW}$, did not differ from that observed in either control group. It suggests that these Cftr knockout mice, although much smaller than their controls, are able to maintain normal ventilation in air and did not exhibit severe lung pathology as observed in children with chronic bacterial infection (1). It should be noted that $\mathrm{Cftr}^{-1-}$ mice were housed in a pathogen-free environment up to weaning, but they also stayed thereafter in a standard animal facility for $1 \mathrm{wk}$ without signs of pulmonary infection as demonstrated by the lung histology. It can also be argued that the young age of $\mathrm{Cftr}^{-1-}$ mice might not allow them to develop severe respiratory affection. However, when the lifespan of $\mathrm{Cftr}^{-1-}$ mice was markedly increased by feeding them with a liquid diet, no severe lung pathology was observed (21).

During hypercapnia, $\mathrm{Cftr}^{-1-}$ and control mice markedly increased $V_{E}$; this effect is achieved by raising both $V_{T}$ and $f$, as observed in juvenile and, thus, small mice (18) in contrast to that found in adult mice, which mainly respond to hypercapnia by an increase in $\mathrm{V}_{\mathrm{T}}(16,17)$.

It is interesting that the response to hypercapnia was unaffected by deletion of the Cftr gene. This finding cannot be compared with other experimental work as, to our knowledge, the regulation of breathing in transgenic animals for CF has not yet been studied, except in a preliminary report (22), but this result differs from that reported in patients with chronic obstructive pulmonary disease (23) and in children with CF (2-4), showing a diminished response to hypercapnia, this effect being related to the degree of obstruction (3).

However, our results showed that the ventilatory response to hypoxia of $\mathrm{Cftr}^{-1-}$ mice is decreased compared with that of controls, in particular at high levels of hypoxia. Such findings have also been reported in children with CF $(2,23)$, although 


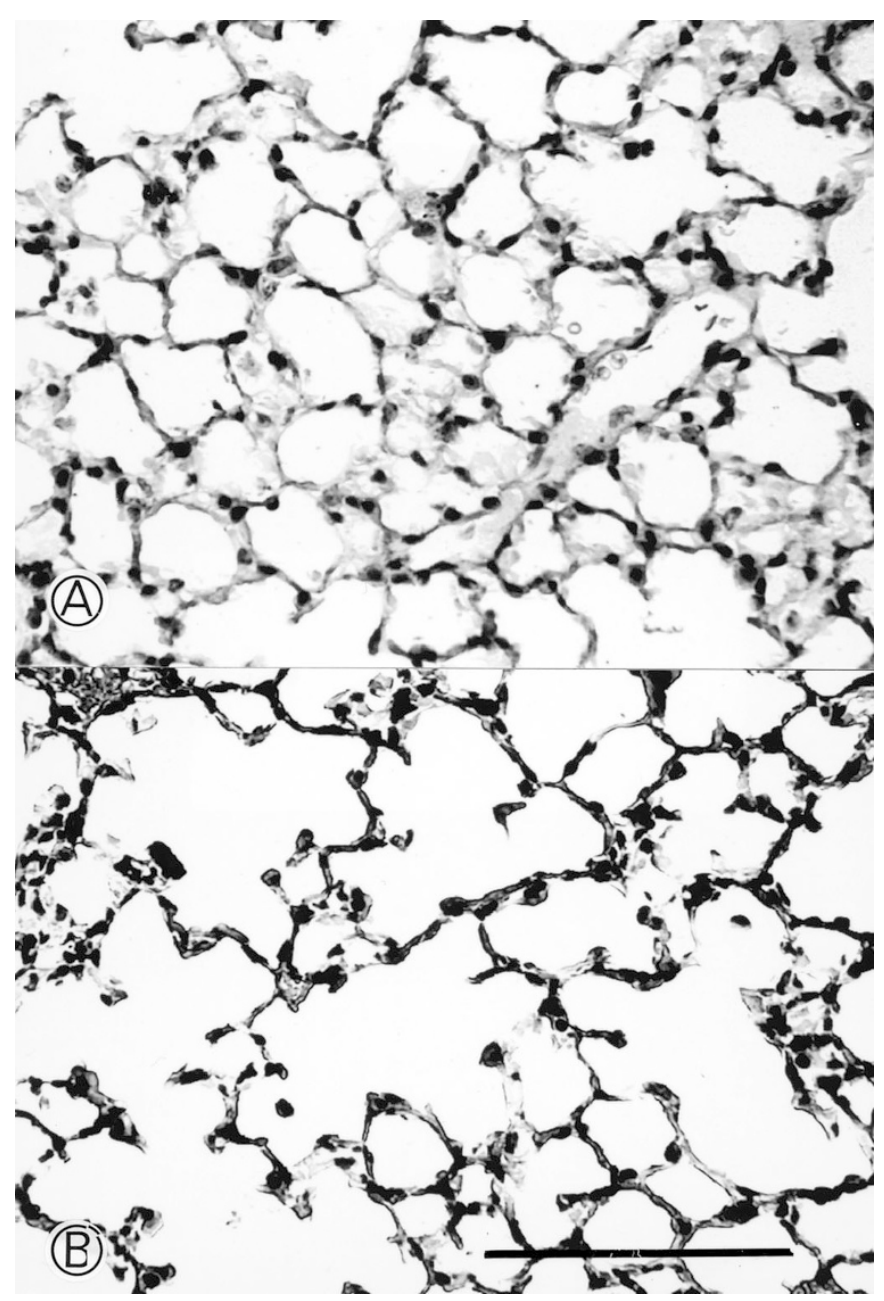

Figure 7. Optical microscopy of lung sections after intratracheal fixation and embedding in paraffin and hematoxylin and eosin staining. Examples of lung from $\mathrm{Cftr}^{+/+}(A)$ and $\mathrm{Cftr}^{-/-}(B)$ mice showing an increase of alveolar size in $\mathrm{Cftr}^{-1-}$ mice. $\mathrm{Bar}=200 \mu \mathrm{m}$.

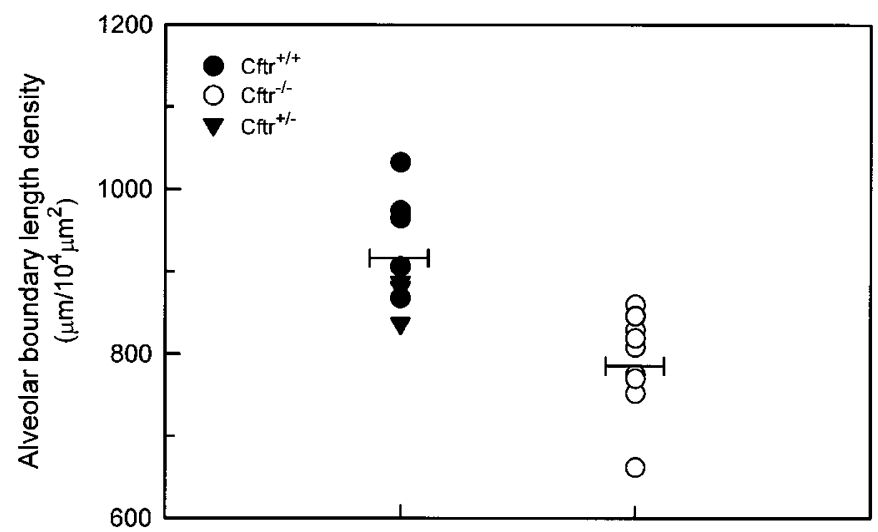

Figure 8. Values of alveolar boundary length density expressed in $\mu \mathrm{m} / 10^{4}$ $\mu \mathrm{m}^{2}$ obtained in the control group including five $\mathrm{Cftr}^{+/+}(\bullet)$ and four $\mathrm{Cftr}^{+/-}$ $(\nabla)$ mice and in the group of nine $\mathrm{Cftr}^{-/-}(\bigcirc)$ mice. The bars indicate the mean in each group.

the decreased $\mathrm{V}_{\mathrm{E}}$ is due to a failure in $\mathrm{V}_{\mathrm{T}}$ in children and to a failure in $\mathrm{f}$ in our mice.

Lung histopathology. In most of the CF mouse models, virtually normal lung histology and absence of mucus plugs in the airways are consistent findings (24). However, minor changes in the respiratory tract have been described in the models with the S489X Cftr mutation. Snouwaert et al. (7) reported tracheal squamous metaplasia and patches of goblet cells in proximal airways. In addition, Kent et al. (8) in congenic strains of this mutation consistently observed patchy lesions with acinar dilation and areas of interstitial thickening without abnormalities of conductive airways. In the present study performed on the same knockout $\mathrm{Cftr}^{-/}$mice initially produced by Snouwaert el al. (7), we did not observe epithelial airway or parenchymal inflammation. These different results could be explained by genetic influences because the marked lung pathology observed by Kent et al. (8) could be related to the use of a nonheterogeneous, congenic background of these knockout mice.

The acinar and alveolar dilation reported by Kent et al. (8) has been observed with low-power examination using light microscopy. In the $\mathrm{Cftr}^{-1-}$ mice of the present study, dilated alveolar morphology was first observed by routine optical examination but was further confirmed by quantitative morphometric analysis. Such an approach for evaluating the architecture of the lung in CF mouse models has not been used before, except in old mice with a different mutation (25). This dilation of alveolar air spaces could be due to either airway obstruction or an impaired process in postnatal development (26). Because we did not observe distal airway alterations such as mucus plugs or epithelial changes, it can be hypothesized that this pattern of decreased alveolar surface could stem from reduced alveolar formation.

Mechanisms. A study performed with patients with CF revealed an attenuation of both the hypoxic and hypercapnic ventilatory response (2) corresponding to the degree of airway obstruction (3). The knockout mice for Cftr function have a normal hypercapnic ventilatory response but a blunted hypoxic ventilatory response. These findings suggest that the alteration in the hypoxic ventilatory response is secondary to the primary abnormality of respiratory control rather than impairment in respiratory apparatus mechanics. We did not perform pulmonary function tests, but no luminal obstruction of intrapulmonary airways was observed in our knockout mice when using a similar procedure of intratracheal lung fixation to that used by Kent et al. (8). Therefore, it seems that $\mathrm{Cftr}^{-1-}$ mice had no major airway obstruction, which is consistent with only minor lung pathology that has been found in these mice by several authors $(7,8)$.

Several factors may have played a role in the decreased ventilatory response to severe hypoxia in $\mathrm{Cftr}^{-1-}$ mice. First, a slight chronic hypoxemia may have altered the process of maturation of carotid bodies and thus the hypoxic drive (27, 28), as observed in children who live at high altitude (29). However, these effects on peripheral chemoreceptors seem to occur only with long-term and severe hypoxemia, which was probably not the case in our mice as their baseline ventilation and ventilatory response to hypercapnia were similar to that of control animals.

The smaller size of the $\mathrm{Cftr}^{-1-}$ mice compared with their littermates can partly explain these findings. In small animals that have a high respiratory system compliance with a high cost 
of breathing, hyperpnea is mostly achieved by using a strategy that will cost less in energy. Therefore, during hypoxia, when the energy supply to the muscles is decreased, mice preferentially increase their $\mathrm{f}$ instead of increasing $\mathrm{V}_{\mathrm{T}}$, which will induce a distortion of the thorax with high resistive work (30). This ventilatory strategy has been recently observed in juvenile mice during hypoxia (18) and in our mice from the control group. However, in very small $\mathrm{Cftr}^{-/-}$mice exposed to severe hypoxia, the strategy of increasing ventilation to improve $\mathrm{O}_{2}$ delivery may be relieved by metabolic adaptation.

Indeed, metabolism is known to be a determining factor in the ventilatory response to hypoxia. The hyperventilation needed to preserve homeostasis can be obtained with hyperpnea or hypometabolism or both, the degree of hypoxic hyperpnea being adjusted to the metabolic response (31). Many adult animals respond preferentially with hyperpnea, but in small species and newborns, hypometabolism may overcome hyperpnea to allow survival by sparing precious $\mathrm{O}_{2}$ in favor of the life-supporting organs $(31,32)$. In our $\mathrm{Cftr}^{-/-}$mice that were much smaller than control littermates, their response to hypoxia may have been essentially a marked decrease in metabolism. Although we did not measure metabolism, the marked fall in rectal temperature at $8 \% \mathrm{O}_{2}$ observed in these mice may provide some insight into potential metabolic changes. Moreover, the normal ventilatory response to hypercapnia with a moderate change in rectal temperature is consistent with this assumption as hypercapnia is less dependent on changes in $\mathrm{O}_{2}$ consumption (33).

Finally, malnutrition may also be responsible for delayed maturation of the respiratory system, in particular at the level of peripheral chemoreceptors and alveolar formation. Indeed, immaturity of peripheral chemoreceptors affects mainly the ventilatory response to hypoxia (34), and in fact that some of our $\mathrm{Cftr}^{-1-}$ mice did not respond or died during severe hypoxia supports this hypothesis. In patients, such a hypothesis has not been documented, but malnutrition has been shown to affect control of breathing as clinical semistarvation induced a depression in the hypoxic ventilatory response, whereas the response to hypercapnia was unaffected (35).

The deleterious effects of malnutrition on alveolar formation and lung growth have been reported in several animal and human studies. In children with CF, progressive lung dysfunction, possibly mediated by impaired lung growth, has been associated with malnutrition $(36,37)$, and in rats, an immaturity in the lung architecture has been observed after underfeeding them $(26,38)$. In many mammalian species, the formation of pulmonary alveoli occurs to a substantial extent after birth, and in mice, postnatal lung development is completed by $2 \mathrm{wk}$ (39), but malnutrition may slow the rate of alveolarization and thus the gas-exchange region $(26,38,40)$. Such a hypothesis is supported by our morphometric observations clearly showing dilation of alveolar air spaces that likely originate from reduced postnatal development of lung alveoli.

In conclusion, the present work has shown that knockout mice for CFTR function, which are markedly underweight, have normal baseline breathing and ventilatory response to hypercapnia. In contrast, their ventilatory response to severe hypoxia is markedly diminished. The mechanisms involved in this phenomenon could be related to the small size of these mice, suggesting high cost of breathing and metabolic requirements, which can be a limiting factor at high levels of hypoxia. Moreover, malnutrition may have induced delayed maturation of the respiratory system and of alveolar formation. This latter finding is consistent with the dilated lung morphology that we have observed in $\mathrm{Cftr}^{-1-}$ mice.

Acknowledgments. We thank members of the CNRS Center de Développement des Techniques Avancées pour l'Experimentation Animale (Orléans, France), in particular M.-F. Bertrand, for providing the mice, J. Chandellier for preparing the illustrations, and Lydie Germain and Nicole Maurin for help in morphometric analysis. We are also grateful to Prof. H. Gautier for advice and useful suggestions.

\section{REFERENCES}

1. Boat TF, Welsh MJ, Beaudet AL 1989 Cystic fibrosis. In: Scriver CR, Beaudet SW (eds) The Metabolic Basis of Internal Diseases. McGraw Hill, New York, pp 2649-2680

2. Bureau MA, Lupien L, Begin R 1981 Neural drive and ventilatory strategy of breathing in normal children, and in patients with cystic fibrosis and asthma. Pediatrics 68:187-194

3. Coates AL, Desmond KJ, Milic-Emili J, Beaudry PH 1981 Ventilation, respiratory center output, and contribution of the rib cage and abdominal components to ventilation during $\mathrm{CO}_{2}$ rebreathing in children with cystic fibrosis. Am Rev Respir Dis 124:526-530

4. Lwin N, Giammona ST 1972 Ventilatory responses to inspired $\mathrm{CO}_{2}$ in patients with cystic fibrosis. Chest 61:206-212

5. Riordan JR, Rommens JM, Kerem B, Alon N, Rozmahel R, Grzelczak Z, Zielenski J, Lok S, Plavsic N, Chou J, Drumm ML, Iannuzzi MC, Collins FS, Tsui L 1989 Identification of the cystic fibrosis gene: cloning and characterization of complementary DNA. Science 245:1066-1073

6. Davidson DJ, Rolfe M 2001 Mouse models of cystic fibrosis. Trends Genet 17:S29S37

7. Snouwaert JN, Brigman KK, Latour AM, Malouf NN, Boucher RC, Smithies O, Koller BH 1992 An animal model for cystic fibrosis made by gene targeting. Science 257:1083-1088

8. Kent G, Iles R, Bear CE, Huan LJ, Griesenbach U, McKerlie C, Frndova H, Ackerley C, Gosselin D, Radzioch D, O'Brodovich H, Tsui LC, Buchwald M, Tanswell AK 1997 Lung disease in mice with cystic fibrosis. J Clin Invest 100:3060-3069

9. Bartlett D Jr, Tenney M 1970 Control of breathing in experimental anemia. Respir Physiol 10:384-395

10. Tschanz SA, Burri PH 2002 A new approach to detect structural differences in lung parenchyma using digital image analysis. Exp Lung Res 28:457-471

11. Cau P 1990 Microscopie Quantitative (Quantitative Microscopy). Editions Inserm, Paris, pp 18-25

12. Glantz SA 1981 Primer of Biostatistics. McGraw-Hill, New York, pp 87-90

13. Snouwaert JN, Brigman KK, Latour AM, Iraj E, Schwab U, Gilmour MI, Koller BH 1995 A murine model of cystic fibrosis. Am J Respir Crit Care Med 151:S59-S64

14. Stahl WR 1967 Scaling of respiratory variables in mammals. J Appl Physiol 22:453460

15. Jacky JP 1978 A plethysmograph for long-term measurements of ventilation in unrestrained animals. J Appl Physiol 45:644-647

16. Tankersley CG, Fitzgerald RS, Kleeberger SR 1994 Differential control of ventilation among inbred strains of mice. Am J Physiol 267:R1371-R1377

17. Onodera M, Kuwaki T, Humada M, Masuda Y 1997 Determination of ventilatory volume in mice by whole body plethysmography. Jpn J Physiol 47:317-326

18. Nakamura A, Kuwaki T, Kuriyama T, Yanagisawa M, Fukuda Y 2000 Normal ventilation and ventilatory responses to chemical stimuli in juvenile mutant mice deficient in endothelin-3. Respir Physiol 124:1-9

19. Dauger S, Nsegbe E, Vardon G, Gaultier C, Gallego J 1998 The effects of restraint on ventilatory responses to hypercapnia and hypoxia in adult mice. Respir Physiol 112:215-225

20. Parot S, Bonora M, Gautier H, Marlot D 1984 Developmental changes in ventilation and breathing pattern in unanesthetized kittens. Respir Physiol 58:253-262

21. Kent G, Oliver M, Foskett K, Frndova H, Durie P, Forstner J, Forstner GG, Riordan JR, Percy D, Buchwald M 1996 Phenotypic abnormalities in long-term surviving cystic fibrosis mice. Pediatr Res 40:233-241

22. Bonora M, Bernaudin JF, Brahimi-Horn C 2001 Ventilatory responses to hypercapnia and hypoxia in conscious cystic fibrosis knockout mice $\left(\mathrm{Cftr}^{-/}\right)$. Pflugers Arch 442:R91

23. Bradley CA, Fleetham JA, Anthonisen NR 1979 Ventilatory control in patients with hypoxemia due to obstructive lung disease. Am Rev Respir Dis 120:21-30

24. Grubb BR, Boucher RC 1999 Pathophysiology of gene-targeted mouse models for cystic fibrosis. Physiol Rev 79(suppl 1):S193-S214 
25. Geiser M, Zimmermann B, Baumann M, Cruz-Orive LM 2000 Does lack of Cftr gene lead to developmental abnormalities in the lung? Exp Lung Res 26:551-564

26. Massaro D, Massaro GD 2002 Invited review: pulmonary alveoli: formation, the "cal for oxygen," and other regulators. Am J Physiol 282:L345-358

27. Hertzberg T, Hellström S, Holgert H, Lagercrantz H, Pequignot JM 1992 Ventilatory response to hyperoxia in newborn rats born in hypoxia-possible relationship to carotid body dopamine. J Physiol 456:645-654

28. Okubo S, Mortola JP 1990 Control of ventilation in adult rats hypoxic in the neonatal period. Am J Physiol 259:R836-R841

29. Lahiri S 1984 Respiratory control in Andean and Himalayan high-altitude natives. In: West JB, Lahiri S (eds) High Altitude and Man. American Physiological Society, Bethesda, pp 147-162

30. Mortola JP 1984 Breathing pattern in newborns. J Appl Physiol 56:1533-1540

31. Mortola JP, Matsuoka T, Saiki C, Naso L 1994 Metabolism and ventilation in hypoxic rats: effect of body mass. Respir Physiol 97:225-234

32. Frappell P, Lanthier C, Baudinette RV, Mortola JP 1992 Metabolism and ventilation in acute hypoxia: a comparative analysis in small mammalian species. Am J Physiol 262:R1040-R1046
33. Mortola P, Lanthier C 1996 The ventilatory and metabolic response to hypercapnia in newborn mammalian species. Respir Physiol 103:263-270

34. Saetta M, Mortola JP 1987 Interaction of hypoxic and hypercapnic stimuli on breathing pattern in the newborn rat. J Appl Physiol 62:506-512

35. Doekel RC, Zwillich CW, Scoggin CH, Kryger M, Weil JV 1976 Clinical semistarvation: depression of hypoxic ventilatory response. N Engl J Med 295:358-361

36. Wilson DO, Rogers RM, Hofman RM 1985 Nutrition and chronic lung disease. Am Rev Respir Dis 132:1347-1365

37. Thomson MA, Quirck P, Swanson CE, Thomas BJ, Holt TL, Francis PJ, Shepherd RW 1995 Nutritional growth retardation is associated with defective lung growth in cystic fibrosis: a preventable determinant of progressive pulmonary dysfunction. Nutrition 11:350-354

38. Sahebjami H 1993 Nutrition and lung structure and function. Exp Lung Res 19:105-124

39. Amy RW, Bowes D, Burri PH, Haines J, Thurbeck WM 1977 Postnatal growth of the mouse lung. J Anat 124:131-151

40. Gaultier C 1991 Malnutrition and lung growth. Pediatric Pulmonol 10:278-286 